\title{
Withdrawn notice
}

Spicer J, Tischer B, Peters M. P176 Epidermal Growth Factor Receptor (EGFR) Mutation Testing and Treatment Choice in Advanced Non-small Cell Lung Cancer (NSCLC): UK Findings from a Global Survey. Thorax 2015;70:A165. doi:10.1136/thoraxjnl-2015207770.313

This abstract has been withdrawn.

Thorax 2016;71:222. doi:10.1136/thoraxjnl-2015-207770.313wthn

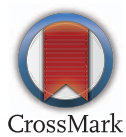

